\title{
PROTECTION AGAINST EXPULSION IN THE EUROPEAN CONVENTION ON HUMAN RIGHTS
}

\section{Elżbieta Hanna Morawska*}

Key words: right of asylum, Universal Declaration of Human Rights, prohibitions on expulsion of aliens, European Convention on Human Rights, prohibition of ill-treatment, right to life, obligation to prevent Abstract: The purpose of this article is to conduct a critical analysis of the premises of protection of an alien elaborated by the ECHR against arbitrary and ECHR-incompatible expulsion from the territory of the State Party to the ECHR. The scope of the institutionalization of the individual's right of asylum in international human rights law was first discussed so as to provide the background of this prohibition. Subsequently, the article presents the process of an inclusion of the issue of expulsion of aliens to the scope of the prohibition of ill-treatment. Thanks to this extensive interpretation of the prohibition of ill-treatment, the ECtHR has developed a particular mechanism of protecting aliens from expulsion, both in the material and procedural dimension. As a result, protection against expulsion under Article 3 of the Convention is outlined more broadly than protection under the 1951 Geneva Convention relating to the Status of Refugees.

* dr hab. - Faculty of Law and Administration of Cardinal Stefan Wyszyński University in Warsaw. 


\section{Introduction}

According to data from the European Border and Coast Guard Agency (Frontex), around 1.83 million people entered the European Union illegally in 2015, i.e. four times more than in $2014^{1}$. Many claim the resulting challenge faced by European States was one of the greatest since the end of World War $\mathrm{II}^{2}$. In trying to meet that challenge, Europe decided to implement a number of measures to alleviate the effects of the immigration crisis. They included resettlement, relocation and forced returns of illegal immigrants ${ }^{3}$. Those were not entirely novel measures, especially the institution of forced returns of aliens that already had a certain history ${ }^{4}$. What is more, it was shaped, at least to a certain extent, with reference to the European Convention on Human Rights (Convention/ECHR) ${ }^{5}$.

With that being said, from a formal point of view, the issue chosen for this analysis may raise certain reservations, given that it is difficult to find any mention of the right of asylum in the text of the Convention'. In addition, among the cases in which an individual may be deprived of liberty, the ECHR allows the possibility of a lawful arrest or detention of an individual with a view to preventing their illegal entry into the territory of a state, or an individual against whom expulsion or extradition proceedings are pending (Article 5 para. 1 point $f$ of the ECHR) ${ }^{7}$. Although the States Parties to the ECHR also decided to include freedom

1 The current status of the agency is governed by Regulation (EU) 2016/1624 of the European Parliament and of the Council of 14.9.2016 on the European Border and Coast Guard and amending Regulation (EU) 2016/399 of the European Parliament and of the Council and repealing Regulation (EC) No. 863/2007 of the European Parliament and of the Council, Council Regulation (EC) No. 2007/2004 and Council Decision 2005/267/EC.

2 See e.g. M. Duszczyk, Kryzys migracyjny [Migration Crisis], 'Biuletyn Instytutu Zachodniego' 2015, no. 205.

3 See e.g. A. Adamczyk, Kryzys imigracyjny w UE i sposobyjego rozwiazzania [Migration Crisis and Means of its Solution], 'Przegląd Politologiczny' 2016, vol. 3, pp. 41-65.

4 See Directive of the European Parliament and of the Council 2008/115/EC of 16.12.2008 on common standards and procedures in Member States for returning illegally staying third-country nationals.

5 Convention for the Protection of Human Rights and Fundamental Freedoms (CETS No.: 005); opened for signature on 4.11.1950; entered into force on 3.9.1953.

6 T. Einarsen, The European Convention on Human Rights and the Notion of an Implied Right to de facto Asylum, 'International Journal of Refugee Law' 1990, vol. 2, p. 362.

7 See also Article 16 of the Convention. 
of movement, prohibition of collective expulsion of aliens and procedural guarantees regarding the expulsion of aliens to the catalog of human rights and fundamental freedoms, they did so in optional protocols to the ECHR. Accordingly, these are Protocol No. 4 of $1963^{8}$ and Protocol No. 7 of $1984^{9}$. The lack of reference to asylum in the catalog of the ECHR's rights and fundamental freedoms demonstrates that its authors were not following the trail of Article 14 of the Universal Declaration of Human Rights, (Declaration/UDHR) ${ }^{10}$, and thus confirms their selective approach towards the universal catalog of human rights ${ }^{11}$. This state of affairs can be explained in two ways. First, it seems that it was determined by the real conditions of work on the Convention, including the economic and social circumstances in post-war Europe, completely exhausted and burnt out by World War II. The existing economic ties were discontinued, and nearly all major centers of heavy industry or production were underperforming, if they had not been destroyed. In addition, it was a time of great political instability, accompanied by significant socio-economic tensions perceived as a real threat to democracy and freedom. Under these circumstances, Europe did not feel ready to ensure the protection of rights and the admission of a multitude of refugees and displaced persons devoid of shelter or resources ${ }^{12}$. Second, the legal conditions underlying the ECHR were of great significance. The preparatory work clearly shows that the catalog of human rights and fundamental freedoms to be contained in the ECHR was limited to "those rights and fundamental freedoms that [have been] guaranteed in all democratic states because [nationals of those countries] have been enjoying them for a long time and [States have some] experience

8 Protocol No. 4 to the Convention for the Protection of Human Rights and Fundamental Freedoms, securing certain rights and freedoms other than those already included in the Convention and in the first Protocol thereto (ETS No. 046); opened for signature on 16.9.1963, entered into force on 2.9.1968.

9 Protocol No. 7 to the Convention for the Protection of Human Rights and Fundamental Freedoms, (ETS No. 017). Opened for signature on 22.11.1984. entered into force on 1 November 1988.

10 Universal Declaration of Human Rights, Resolution 217/III, adopted by the General Assembly, (A/RES/3/217) on 10.12.1948.

11 Therefore, the preamble to the Convention mentions the taking of first steps by governments for the collective enforcement of certain rights stated in the Universal Declaration (recital 5).

12 In many cases it was linked with the threat to Europe from the Soviet Union. See E. Bates, The Evolution of the European Convention on Human Rights: from its Inception to the Creation of a Permanent Court of Human Rights, Oxford 2010, p. 5. 
in this area"13. Thus, the ECHR included human rights and freedoms, in respect of which it was possible to agree not only on their definition, but also on extending over them the conventional supervision of the ECHR judicial bodies ${ }^{14}$. This attitude points to the authors' great pragmatism, as well as their consciousness of the fragility of the consent obtained from the Member States of the Council of Europe as to the limitation of their exclusive sovereignty in the field of human rights and freedoms ${ }^{15}$.

However, ECHR law does not constitute just the text of the Convention, but also the case law of its bodies: the European Court of Human Rights (Court / ECtHR) ${ }^{16}$ and the European Commission on Human Rights (Commission / EComHR $)^{17}$ supporting the former in the first period

13 Council of Europe, Cons. Ass., First session, Reports, 1949, p. 1144. This is why the provisions that raise the most reservations, i.e. protection of property, right to education and free elections, have been regulated in an optional Additional Protocol. It was opened for signature on 20.3.1952 and entered into force on 18.5.1954. (CETS No. 009). See also P.H. Teitgen, as cited in L. E. Pettiti, E. Decaux, P. H. Imbert (ed.), La Convention européenne des droits de l'homme: Commentaire article par article, Paris 1998, p. 6.

L. Zwaak, General Survey of the European Convention, [in:] P. van Dijk, F. van Hoof, A. van Rijn, L. Zwaak (eds.), 'Theory and Practice of the European Convention on Human Rights', Antwerp 2006, p. 5.

15 E. Bates, op. cit., p. 9. M. Rask Madsen, From Cold War Instrument to Supreme European Court: the European Court of Human Rights at the Crossroads of International and National Law and Politics, 'Law \& Social Inquiry' 2007, vol. 32, pp. 137-59.

16 In accordance with Article 19 of the Convention, the ECtHR is to "ensure the observance of the engagements undertaken by the High Contracting Parties". It was established only in 1959; the first session was held on 23-28.2.1959, and the first judgement on the merits was issued on 1.7.1963; this was the case of Lawless v. Ireland, no. 332/57. Under Protocol No. 11 to the Convention, the Court is currently the only judicial body of the Convention. Cf. Protocol No. 11 to the Convention for the Protection of Human Rights and Fundamental Freedoms, restructuring the control machinery established thereby (ETS No. 155). It was opened for signature on 11.5.1994 and entered into force on 1.11.1998 r. (Polish Official Journal of 1998, no. 147, item 962). For circumstances of the introduction of P-11 see B. Gronowska, Europejski Trybunat Praw Człowieka. W poszukiwaniu efektywnej ochrony praw jednostki [European Court of Human Rights. In search of effective protection of individual rights], Wydawnictwo TNOiK, Toruń 2011, p. 47; similarly L. Garlicki (ed.) Konwencja o Ochronie Praw Człowieka i Podstawowych Wolności. T.2. Komentarz do artykułów 19-59 oraz do Protokołów dodatkowych [European Convention for Human Rights and Fundamental Freedoms, a Commentary to Articles 19-59 and to Additional Protocols], Warszawa 2011, p. 5.

17 EComHR was established in 1954; it addressed the first complaint in 1955. The EComHR was not a judicial body sensu stricto, and its task was to strive at all 
of its activity. These authorities, through application and interpretation of the Convention, introduced to the scope of certain human rights and fundamental freedoms issues that pertained to protection against the unlawful expulsion under the Convention, in which reference could be made to the principle of non-refoulement, which is a fundamental principle of the international protection of refugees ${ }^{18}$.

Anticipating the detailed remarks, it should be emphasized that due to Article 1 of the Convention ${ }^{19}$, i.e. as a result of its interpretation, the structure and nature of the obligations of the State Parties related to these rights have been significantly modified. Additionally, their beneficiary could now be any person under their jurisdiction, where the lack of refugee status within the meaning of Article 1A of the Convention relating to the Status of Refugees (Geneva Convention) ${ }^{20}$ does not exempt these States from the performance of obligations under the ECHR ${ }^{21}$. What is more, the performance of these obligations does not exempt the State Parties from their powers to control the entry, residence and expulsion of aliens. Although the ECHR judicial bodies emphasize that these rights are well-established in international law, they have also ruled that States can use these rights only with respect for human rights and fundamental freedoms set out in the Convention. The ruling tendency in this regard was established by the EComHR in 1958, stating that:

times to for amicable conciliation and settlement. It ended all activity under P-11. Cf. Explanatory Report, Protocol No. 11 to the Convention for the Protection of Human Rights and Fundamental Freedoms, restructuring the control machinery established thereby, ETS No. 155, item 56.

18 See e.g. M.S.S. v. Belgium and Greece, no. 30696/09, ECtHR judgment of 21.1.2011; for more recent cases: Khlaifia and Others v. Italy, no. 16483/12, ECtHR judgment of 15.12.2016.

19 E. Morawska, Zobowiqzania pozytywne państw-stron Konwencji o ochronie praw człowieka i podstawowych wolności [Positive Obligations of Parties to ECHR], Warszawa 2016, p. 89 et seq.

20 Convention relating to the Status of Refugees, Adopted on 28.7.1951; entry into force on 22.04.1954. (United Nations, Treaty Series, vol. 189, p. 137). See D. A. Martin, Reforming Asylum Adjudication: On Navigating The Coast of Bohemia, 'University of Pennsylvania Law Review' 1990, vol. 138, p. 1255; Ch. Tomuschat, A Right to Asylum in Europe, 'Human Rights Law Journal' 1992, vol. 13, p. 258.

21 M. Kowalski, Pomiędzy uznaniowością a zobowiązaniem: podstawy prawnomiędzynarodowej ochrony uchodźców [Between discretion and obligation: legal bases of international protection of refugees], 'Politeja' 2016, vol. 1, p. 443. 
A state which signs and ratifies the European Convention on Human Rights must be understood as agreeing to restrict the free exercise of its rights under general international law, including the right to control the entry and exit of foreigners to the extent and within the limits of the obligations it has accepted under the Convention ${ }^{22}$.

\section{Scope of analysis}

In light of the above remarks, it is justified to first establish the scope of the institutionalization of the right of an individual to asylum in international human rights law. The above findings will constitute a background for the evaluation made by ECHR judicial bodies regarding the expansion of the scope of application of certain human rights and fundamental freedoms, and related obligations of the States Parties to the ECHR. Among these human rights and fundamental freedoms, an extensive interpretation of the prohibition of ill-treatment (Article 3 of the Convention) was of fundamental importance.

The limited framework of this article does not allow for a detailed analysis of specific cases decided by the Court, therefore it will address only those of them that predominate and as such demarcate the ECHR case law line in the scope under consideration. Nevertheless, the subject of the following analysis is the ECtHR case law tendency at a particular stage of its development, which is why one should bear in mind the farreaching dynamics of Strasbourg case law in the analyzed scope.

\section{Right of asylum in international human rights law}

The scope of the institutionalization of the right of asylum in international human rights law is extremely narrow since only the Declaration refers to it expressis verbis. In accordance with Article 14 of the Declaration, any person has the right to apply for asylum and enjoy it in another country in the event of persecution, adding in the second paragraph that it cannot be invoked in the case of prosecution actually 
initiated for a common crime or an act contrary to the objectives and principles of the United Nations (UN) ${ }^{23}$. It is particularly noteworthy that the Declaration, which constitutes the above law, fails to explain what it means by the term "asylum", thereby leaving that issue open to discussion and perpetuating the current state of affairs since, despite its long history and widespread use, it is difficult to indicate the universally recognized definition of "asylum".

In the literature, the papers referring to the right of asylum refer to it is a right that should be placed between the rights of a sovereign state and human rights ${ }^{24}$. Consequently, it has an extremely complex internal structure, with a total of three aspects pointed out in this respect. The first has to do with the right of an individual to apply for, or seek, asylum, the second - with the right of the State to grant asylum, and the third with the right of an individual to obtain, or be granted, asylum ${ }^{25}$.

The already mentioned Article 14 of the Declaration refers to the first of these aspects, and thus to the individual's right to apply for asylum. A. Grahl-Madsen aptly stresses that this is an individual right that the asylum seeker enjoys with respect to their country of origin ${ }^{26}$. This right does not impose any obligations on either the potential or the current receiving State because its essence is the individual's right to leave the country of residence in search of asylum ${ }^{27}$, but this is not an absolute right, and in certain circumstances may be subject to restrictions ${ }^{28}$. This right of the individual is confirmed expressis verbis by the Declaration ${ }^{29}$,

23 See footnote no. 7.

24 See e.g. P. Kourula, Broadening the Edges: Refugees Definition and International Protection Revisited, The Hague 1997, p. 273; C. d'Orsi, The AU Convention on Refugees and the Concept of Asylum, 'Pace International Law Review Online Companion' 2012, vol. 3, no. 7, p. 226; G. S. Goodwin-Gill, J. McAdam, The Refugee in International Law, Oxford 2007, p. 365.

${ }_{25}$ See A. Grahl-Madsen, Territorial Asylum, Stockholm 1980; R. Boed, The State of the Right of Asylum in International Law, 'Duke Journal of Comparative \& International Law' 1994, vol. 5, p. 3.

26 A. Grahl-Madsen, Territorial Asylum..., p. 2; K. Hailbronner, Molding a New Human Rights Agenda, 'Washington Quarterly' 1985, vol. 8, p. 183 et seq.

27 A. Grahl-Madsen, The Status of Refugees in International Law, vol. II, Leyden 1972, p. 26.

28 See comments about the possibility of limiting the right to apply for and enjoy asylum. E.g. F. Morgenstern, The Right of Asylum, 'British Yearbook of International Law' 1949, vol. 26, pp. 331-335.

29 See Article 13 para. 2 of the Declaration. 
the International Covenant of Civil and Political Rights (ICCPR) ${ }^{30}$ and regional documents concerning international human rights protection, including Protocol No. 4 to the ECHR ${ }^{31}$ and the American Convention on Human Rights ${ }^{32}$.

The second aspect of the right of asylum concerns the right of the State to grant asylum. This provision is well-established in international law and it stems from the principle of territorial sovereignty of States, according to which every sovereign State has exclusive control over its territory, and thus over persons residing therein ${ }^{33}$. One of the consequences of this universally recognized principle is the right of a State to grant or refuse asylum to persons residing within its territory ${ }^{34}$. Thus, on the basis of international law, the right of asylum was perceived more in terms of State rights rather than individual rights ${ }^{35}$. Interestingly, proponents of Article 14 of the Declaration were driven by very much the same ideals ${ }^{36}$. It was

30 Article 12 para. 2 of the International Covenant on Civil and Political Rights, adopted by General Assembly resolution 2200 (XXI) on 16.12.1966 (United Nations, Treaty Series, vol. 999, p. 171 and vol. 1057, p. 407).

${ }^{31}$ Article 2 para. 2 of the Council of Europe Agreement No. 46: Protocol No. 4 to the European Convention for the Protection of Human Rights and Fundamental Freedoms (ETS No. 046).

32 Article 22(2) of the American Convention on Human Rights, adopted at the InterAmerican Specialized Conference on Human Rights, San José, Costa Rica, 22.11.1969.

${ }^{33}$ See. J. Krantz, Państwo i jego suwerenność [The State and its Sovereignty], 'Państwo i Prawo' 1996, no. 7, p. 5 et seq.; cf. J. Czaputowicz, Rola państwa w Unii Europejskiej [The Role of the State within the European Union], Centrum Europejskie Natolin, Warszawa 2004, p. 4 et seq.; R. Kwiecień, Suwerenność państw: rekonstrukcja i znaczenie idei w prawie międzynarodowym [State Sovereignty: Reconstruction and the Meaning of the Idea in International Law], Kraków 2004. See also R. Kwiecień (ed.), Państwo a prawo międzynarodowe jako system prawa [The State and International Law as a Legal System], Lublin 2015; for relationship between sovereignty and human rights see F. Capotorti, Human Rights: the Hard Road Towards Universality, [in:] R. St. J. MacDonald, D. M. Johnston, 'The Structure and Process of International Law: Essays in Legal Philosophy Doctrine and Theory', Dordrecht-Boston-London 1991, pp. 977-1000; for right of asylum see e.g. F. Morgenstern, op. cit. p. 327.

34 A. Grahl-Madsen, Territorial Asylum... p. 23; similarly S. Prakash Sinha, Asylum and International Law, The Hague, 1971, p. 50; F. Morgenstern, op. cit., p. 327.

35 See e.g. G. S. Goodwin-Gill, J. McAdam, op. cit., p. 357 along with the literature items contained therein.

${ }^{36}$ The initiative of proclaiming Article 14 in the Declaration was prompted by the British delegation. As emphasized by H. Lauterpacht, when submitting said proposal, the British delegation understood the right of asylum as "the right of every State to offer shelter and resist extradition requests". According to $\mathrm{H}$. Lauterpacht, that right is one 
essentially upheld in the UN Declaration on Territorial Asylum of $1967^{37}$ and in regional documents such as: the Convention Governing the Specific Aspects of Refugee Problems in Africa of the Organization of African Unity $^{38}$, the Convention on Territorial Asylum of the Organization of American States ${ }^{39}$, or the 1977 Declaration of the Committee of Ministers of the Council of Europe on Territorial Asylum whose Article 2 states that Member States of the Council of Europe "(...) reaffirm their right to grant asylum" 40 .

The third aspect of the right of asylum is the individual's right to actually obtain asylum. It should be noted that it is difficult to indicate specific documents that expressly contain the aforementioned right as a right upon which a particular State would be obliged to provide asylum to an individual. This is due to the invariable predominance of $\mathrm{F}$. Morgenstern's argument that "there is no doubt that an individual has no general right of asylum with respect to a [given] State" ${ }^{41}$. In the light of preparatory works, one cannot conclude that such a right derives from

that "every state... is granted under international law." Cf. H. Lauterpacht, The Universal Declaration of Human Rights, 'British Yearbook of International Law' 1948, vol. 25, p. 373; idem, International Law and Human Rights, London 1950, p. 421; see also description of works on Article 14 of the UDHR: G. S. Goodwin-Gill, J. McAdam, op. cit., p. 359 et seq.; A. Florczak, Uchodźcy w Polsce. Między humanitaryzmem a pragmatyzmem [Refugees in Poland. Between Humanitarianism and Pragmatism], Torun 2003, p. 33.

37 It was adopted by the General Assembly of the United Nations in 1967 (Res 2312(XXII), 14.12.1967); see especially Article 1, para. 1, stating that "Asylum granted by a State, in the exercise of its sovereignty, to persons entitled to invoke Article 14 of the Universal Declaration of Human Rights, including persons struggling against colonialism, shall be respected by all other States". In addition, Article 1, para. 3 of the Declaration grants a State the right to "evaluate the grounds for the grant of asylum". According to e.g. P. Weis, including in Article 1, para. 1 of the phrase "in the exercise of its sovereignty" was intended "to explicitly emphasize that asylum is not an individual right, but the right of States to grant asylum"; idem, The United Nations Declaration on Territorial Asylum, 'Canadian Yearbook of International Law' 1969, vol. 7, p. 136.

38 Cf. OAU, Convention Governing the Specific Aspects of Refugee Problems in Africa, Article 11 (1), adopted by the Assembly of Heads of State and Government, 10.9.1969.

39 OAS, Convention on Territorial Asylum, Article 1, adopted during the Tenth Inter-American Conference, Caracas, Venezuela, 28.3.1954.

$40 \mathrm{CoE}$, Committee of Ministers, Article 2 of the Declaration on Territorial Asylum, Adopted by the Committee of Ministers at the $278^{\text {th }}$ meeting of the Ministers' Deputies, 18.11.1977.

41 F. Morgenstern, op. cit., p . 335. 
Article 14 para. 1 of the Declaration ${ }^{42}$. International instruments adopted following the Declaration also fail to provide for the right of asylum as such, and neither do international human rights pacts ${ }^{43}$ or basic international documents on the protection of refugees, namely the Geneva Convention ${ }^{44}$ and the 1967 Protocol relating to the Status of Refugees ${ }^{45}$.

The same applies to regional documents, as they do not, as such, provide for the right of an individual to obtain asylum. Interestingly, both African ${ }^{46}$ and American ${ }^{47}$ regional documents refer to the issue of asylum, but they nevertheless do so with great respect for the sovereignty of the State.

\section{Aspects of the right of asylum in ECtHR case-law}

It is known from previous observations that the Convention is silent on the subject of the individual's right of asylum, although certain aspects of this right are present in ECHR law ${ }^{48}$. It is very telling that a certain

42 See F. Morgenstern, op. cit., pp . 335-336; G. S. Goodwin-Gill, J. McAdam, op. cit., pp. 359-363; R. Boed, op. cit., pp. 8-11.

43 It concerns both covenants: International Covenant on Civil and Political Rights (note no. 25) and International Covenant on Economic, Social and Cultural Rights, adopted by General Assembly resolution 2200A (XXI), 16.12.1966 (United Nations Treaty Series, vol. 993, p. 3).

44 Convention relating to the Status of Refugees, adopted on 28.07.1951; entry into force on 22.4.1954. (United Nations Treaty Series, vol. 189, p. 137). See D. A. Martin, Reforming Asylum Adjudication: on Navigating The Coast of Bohemia, 'University of Pennsylvania Law Review’ 1990, vol. 138, p. 1255; Ch. Tomuschat, A Right to Asylum in Europe, 'Human Rights Law Journal' 1992, vol. 13, p. 258.

45 Protocol relating to the Status of Refugees, adopted on 31.1.1967. (United Nations Treaty Series, vol. 606, p. 267).

46 See Article II (1), OAU, Convention Governing the Specific Aspects of Refugee Problems in Africa; see footnote no. 39.

47 See Article 27 of the American Declaration of the Rights and Duties of Man, adopted by the Ninth International Conference of American States, Bogotá, Colombia, 2.5.1948; See also Article 22 (7) of the American Convention on Human Rights (see footnote 32).

48 The above process coincided with the position of the Parliamentary Assembly of the Council of Europe (see Recommendation 293 (1961), adopted on 30th Ordinary Session, 21-28.9.1961; Recommendation 434 (1965), Yearbook of the Convention, vol. 8, pp. 56-57 [1965]) and with the position of the Committee of Ministers of the Council 
change in this area has been made by the ECHR judicial bodies not so much through interpretation of the rights guaranteed under Protocol 4 or Protocol $7^{49}$, but rather through interpretation that extends the application of the rights and fundamental freedoms contained in the ECHR itself ${ }^{50}$.

The constitutional consequences concerned the extension of the judgements pertaining to extradition contained in the Soering $v$. the UK case of 1989 to the issue of the expulsion of an alien, made for the Cruz Vargas and Others $v$. Sweden case of $1991^{51}$. As known, those judgements referred to the prohibition of ill-treatment. Thus, the Cruz Varas case confirmed the possibility of evaluating the decision of a state-party to the ECHR expel an alien under Article 3 of the Convention ${ }^{52}$. In subsequent cases, the Court allowed the evaluation of such decisions also in the context of the risk to the right to life (Article 2 of the Convention) ${ }^{53}$, the right to respect for private and family life (Article 8 of the Convention) ${ }^{54}$, followed by

of Europe (see e.g. Resolution 67 (14), Yearbook of the Convention, vol. 10, pp. 104-105 [1967]; Declaration on Territorial Asylum, adopted on 18.11.1977, Collected Texts, 1987 edition, p. 202).

49 Protocol No. 4 was not ratified by Greece, Switzerland, Turkey and the United Kingdom. Protocol No. 7 was not ratified by Germany, the Netherlands and the United Kingdom.

50 For the first time, the European Commission of Human Rights held in 1961 "that the deportation of a foreigner to a particular country might in exceptional cases give rise to the question whether there had been 'inhuman treatment'; within the meaning of Article 3 of the Convention" (Decision of the Commission in the case Xv. Federal Republic of Germany of 6.10.1962, Y.B. Eur. Conv. Hum. Rts. 1962, 256 et seq. (260), which refers to the unpublished decision concerning application 984/61). In 1987, the Commission held an application based on Article 3 to be admissible where a person had been expelled by the United Kingdom to the Kingdom of Morocco (Y.B. Eur. Conv. Hum. Rts. 1973, 356). On the whole there are about forty decisions of the commission dealing with this topic, see W. Kälin, Das Prinzip des Non-Refoulement. Das Verbot der Zurückweisung, Ausweisung und Auslieferung von Flüchtlingen in den Verfolgerstaat im Völkerrecht und im schweizerischen Landesrecht, Bern 1982, p. 167 et seq.).

51 See Soering v. the UK, no.14038/88, ECtHR judgement of 07.07.1989, para. 91 and Cruz Varas and Others v. Sweden, no. 15576/89, of 20.3.1991, para 70. The ruling tendency of Cruz Varas was repeated few months later in Vilvarajah and Others v. the UK, no. 13163/87 13164/87 13165/87... et al., ECtHR judgement of 30.10.1991, para. 102 et seq.

$52 \mathrm{CoE}$, Yearbook of the European Convention on Human Rights/Annuaire de la Convention Européenne des Droits de L’Homme 1991, vol. 34, p. 238.

53 See F.G. v. Sweden, no. 43611/11, ECtHR judgement of 23.3.2016, paras 85-127.

54 See Abdulaziz, Cabales and Balkandali v. the UK, no. 9214/80, 9473/81, 9474/81, ECtHR judgement of 28.5.1985; Cruz Varas and Others v. Sweden; Boujlifa v. France, no. 25404/94, ECtHR judgement of 21.10.1997; Jeunesse v. the Netherlands, no. 12738/10, 
the right to liberty and security (Article 5 of the Convention) ${ }^{55}$ and the right to a fair trial (Article 6 of the Convention) ${ }^{56}$. Each of these rights is linked to the right to an effective remedy (Article 13 of the Convention) ${ }^{57}$.

A specific mechanism was thus built, aimed at protecting aliens against arbitrary and ECHR-incompatible expulsion.

\section{Protection against expulsion in the event of the risk of ill-treatment}

Here, the obligation to protect aliens against ill-treatment occupies a unique and important place.

The structure and nature of this obligation has been subordinated to the objective nature of the obligations of States, arising from the ECHR. The consequence of the nature of these obligations is a departure from the principle of reciprocity, which is characteristic of the protection of the individual on the basis of law and diplomatic espousal ${ }^{58}$. As regards the Convention, the resulting objective obligations bind State Parties not only towards their own citizens, but to any person, regardless of nationality, who is subject to their jurisdiction ${ }^{59}$. That tendency of Strasbourg case law was first marked by EComHR in $1961^{60}$. This obligation is not limited

ECtHR judgement of 3.10.2014; B.A.C. v. Greece, no. 11981/15, ECtHR judgement of 13.10.2016.

55 See e.g. Othman (Abu Qatada) v. the UK, no. 8139/09, ECtHR judgement of 9.05.2012.

56 See Mamatkulov and Askarov v. Turkey, no. 46827/99, 46951/99, ECtHR judgement of 4.2.2005; Al-Saadoon and Mufdhi v. the UK, no. 61498/08; Othman (Abu Qatada) v. the UK.

57 See e.g. De Souza Ribeiro v. France, no. 22689/07, ECtHR judgement of 13.12.2012; Amie and Others v. Bulgaria, no. 58149/08, ECtHR judgement of 12.2.2013; A.C. and Others v. Spain, no. 6528/11, ECtHR judgement of 22.4.2014.

58 Cf. J. Sandorski, Opieka dyplomatyczna a międzynarodowa ochrona praw człowieka [Diplomatic protection and International Protection of Human Rights], Poznań 2006; for a traditional model of protection cf. S. Sivakumaran, Impact on the Structure of International Obligations, [in:] M.T. Kamminga, M. Scheinin, 'The Impact of Human Rights Law on General International Law', Oxford 2009, pp. 133-135.

59 International Law Commission Report, Fragmentation of International Law: Difficulties Arising from the Diversification and Expansion of International Law, UN Doc. A/CN.4/L.682, para. 391.

60 Austria v. Italy, no. 788/60, EComHR decision of 11.1.1961. It is worth recalling that the complaint in this case was made because of the conflict surrounding the status of the German-speaking population in South Tyrol. 
to citizens of a given State Party and citizens of other State Parties, but also includes citizens of states that are not parties to the ECHR and even to stateless persons ${ }^{61}$. Decisive in this context is the content of Article 1 of the Convention, which lacks any reference to the institution of citizenship. This pronunciation of Article1 of the Convention is further reinforced by Article 14 of the Convention stating the prohibition of any discrimination in the exercise of rights and freedoms contained therein. As a result, even victims of potential violations that are not citizens of not only the specific state against whom they are accused, but also of any State Party to the Convention, can enjoy guarantees under the ECHR, provided that they are considered to be subject to the jurisdiction of the State concerned ${ }^{62}$.

It is irrelevant whether they have the right to reside in the territory of one or other of the State Parties to the Convention. Finally, in light of Strasbourg case law, the term 'jurisdiction' under Article 1 of the Convention does not imply the obligation to ensure rights and fundamental freedoms is limited only to the territory of the State ${ }^{63}$.

The consequence of the objective nature of obligations under the Convention for States Parties is, moreover, the lack of correlation (interdependence) between the rights of the individual and the obligations of the state because there is one-sidedness of obligations of states towards persons subject to their jurisdiction. The status of these persons as

61 Like many other characteristics, this is also valid for other human rights treaties, as confirmed by the findings e.g. of the Human Rights Committee in its General Comments, No. 24 (52), as well as the Inter-American Court of Human Rights position in the advisory opinion on "Other Treaties" Subject to the Consultative Jurisdiction of the Court, Article 64, American Convention on Human Rights of 24.9.1982, series A, no. 1, 1982; and also in the advisory opinion on The Effect of Reservations in the Entry into Force of the American Convention on Human Rights of 24.9.1982, series A, no. 2, 1982, para. 29-30.

62 Austria v. Italy of 1961, p. 19.

63 During the work on the original text of the Convention, the Consultative Assembly of the $\mathrm{CoE}$ submitted a proposal for the editing of Article 1 of the Convention according to which "all persons residing within the territories of the signatory States", but that motion was rejected by the Committee of Experts. Cf. Collected Edition of the "Travaux Préparatoires' of the European Convention on Human Rights, vol. IV, The Hague, 1977, p. 20: "It was felt that there were good grounds for extending the benefits of the Convention to all persons in the territories of the signatory States, even those who could not be considered as residing there in the legal sense of the word". See also X. v. Federal Republic of Germany, no. 1611/62, EComHR decision of 25.9.1965, in which the Commission found that "in certain respects the nationals of the Contracting State are within its jurisdiction even when domiciled or resident abroad". 
beneficiaries of the ECHR does not depend on the proper performance of obligations towards society or the state, nor obligations towards other persons ${ }^{64}$, and they do not lose it even when they take undesirable or dangerous actions, violate physical and mental integrity, or threaten the lives of others ${ }^{65}$. This aspect of reciprocity assumes particular importance and clarity with regard to the absolute prohibition of ill-treatment.

In light of the judgements of ECHR judiciary bodies, the State Party is bound by the prohibition of expelling an alien in a situation of substantial grounds for the existence in the receiving state of real risk of treatment in breach of Article 3 of the Convention. Such risk should be evaluated in light of facts which were known or ought to have been known to the Contracting State at the time of expulsion, although the facts disclosed later may influence the Court's determination regarding the State's evaluation of the occurrence of the risk in question. In the above findings, reference can be made to the premise of knowledge about the existence of risk, which determines the existence of positive obligations of protection in a given case, the object of which is to take operational preventive measures ${ }^{66}$.

Therefore, the Court declares that its own evaluation of the occurrence of a risk to these rights must be preceded by very precise and meticulous arrangements that may rely on data submitted to it or, if necessary, on data collected motu proprio ${ }^{67}$. In addition, it ensures that the possibility of ill-treatment in the receiving state examines thoroughly and takes into account only the consequences of the alien's expulsion that are foreseeable

64 J. H. Knox, Horizontal Human Rights Law, 'American Journal of International Law' 2008, vol. 102, pp. 1-41.

65 Chahal v. the UK z 1996 r., para. 80. See C. Warbrick, The European Response to Terrorism in an Age of Human Rights, 'European Journal of International Law' 2004, vol. 15, no. 5, pp. 989-1018.

66 It is a premise for the existence of the positive obligations in question not only in the event of a threat to life (Article 2 of the Convention) and ill-treatment, but also in the situation of threats to other rights or fundamental freedoms, including the prohibition of slavery and forced labor (Article 4 of the Convention), the right to liberty and security (Article 5 of the Convention) and the right to respect for physical and mental integrity (Article 8 of the Convention), in relation to threats to the physical and mental integrity of an individual. See Rantsev v. Cyprus and Russia, no. 25965/04, ECtHR judgment of 7.1.2010; Storck v. Germany, no. 61603/00, ECtHR judgement of 16.6.2005; Georgel and Georgeta Stoicescu v. Romania, no. 9718/03, ECtHR judgement of 26.7.2011.

67 See e.g. Saadi v. Italy, no. 37201/06, ECtHR judgment of 28.2.2008, paras 128-133 . With regard to threats to the right to life and ill-treatment, see also F.G. v. Sweden of 2016, paras 85-127. 
in the light of both the general situation in that state and the personal situation of the person to be expelled ${ }^{68}$. The Court strongly emphasizes its extreme caution about the applicant's claims regarding the existence of a risk due to the general situation in the receiving State ${ }^{69}$. An important premise in this case is the occurrence of practice incompatible with the ECHR, supported by the applicant with uncontested evidence ${ }^{70}$.

The confirmation of data collected for the existence of the real risk of ill-treatment in the receiving State significantly affects the evaluation of diplomatic assurances received from the receiving State regarding the risk of treatment contrary to the Convention. This is demonstrated by the Othman (Abu Qatada) v. the UK case of 2012, in which the Court, by collecting its previous judgement, indicated two general requirements of these guarantees. In the first place, these requirements concern the quality of these guarantees ${ }^{71}$ and then their reliability in the light of the host country's practice ${ }^{72}$. The Court adds that it pays attention

68 As in Vilvarajah and Others v. the UK of 1991, para. 108 in fine.

69 In principle, "(...) the Court would not require evidence of individual circumstances only in the most extreme cases where the general situation of violence in the country of destination is of such intensity as to create a real risk that any removal to that country would necessarily violate Article 3". See e.g. N. A. v. the UK, no. 25904/07, ECtHR judgement of 17.7.2008, paras 115-116; Sufi and Elmi v. the UK, no. 8319/07, 11449/07, ECtHR judgement of 28.6.2011, para 217; Savriddin Dzhurayev v. Russia, no. 71386/10, ECtHR judgement of 25.4.2013, para. 153.

${ }^{70}$ It is determined, inter alia, in the light of information obtained from reliable non-governmental organizations. Cf. relatively recent case X. v. Germany, no. 54646/17, ECtHR decision of 7.11.2017, para. 28, in which the ECtHR examined the admissibility of a complaint regarding the decision of deporting to Russia the applicant accused of conducting terrorist activity in Germany, which was considered to pose a threat to state security.

${ }^{71}$ It concerns whether they had been disclosed to the Court, whether they were specific, whether they were binding on the receiving State at both central and local levels and whether their reliability had been examined by the domestic courts of the sending/ Contracting State.

72 This concerns whether the receiving State was a Contracting State, whether it afforded effective protection against torture and outlawed the conduct to which the assurances related, whether it had strong bilateral relations with the sending State and had abided by similar assurances in the past, whether the applicant had previously been poorly treated there and whether adequate arrangements were in place in the receiving State to allow effective monitoring and unfettered access for the applicant to his or her lawyers. 
to whether or not states have made genuine efforts to obtain and submit such guarantees so that they are sufficiently transparent and detailed ${ }^{73}$.

In this way, the prohibition of expulsion gives rise only to the rights for the alien but also specific obligations for State Parties, whose nature seems not to be explicit. This is because, in their structure, one can indicate elements characteristic of negative obligations as well as positive obligations. As to the essence, they should only be negative obligations because these are the primary obligations under the Convention ${ }^{74}$. The subject of these obligations should be a ban on action, i.e. the State Parties should be obliged not to take any actions that would violate the ban on expulsion. Consequently, the State Parties would be liable under the ECHR for taking such measures. Nevertheless, in the case of obligations resulting from the ban on the expulsion of an alien, the obligations of State Parties are not so simple in terms of structure, given that the State Parties were additionally obliged to take specific factual actions (measures) in the field of national practice. Thus, the Court has imposed a positive obligation on the States, whose direct addressees are their executive or judicial authorities. The premise for binding them in a given case is the already mentioned premise of knowledge about the existence in the receiving State of real risk to treatment incompatible with Article 3 of the Convention. States have therefore been obliged to prevent the materialization of the above risk towards the person to be expelled.

The fulfillment of this positive obligation requires taking operational preventive measures (actions). These measures are first indicated by the above diplomatic assurances, and in the absence or insufficient quality or credibility thereof, suspension or withdrawal from the enforcement of the expulsion decision ${ }^{75}$. As regards the latter measures, the recommendations issued by the Court in the form of interim measures play a particularly important role ${ }^{76}$. Their purpose is to safeguard the rights and interests of the parties for the duration of proceedings before the ECtHR. As such, they may be issued in any case, however, the case law review reveals that they are most often issued in cases where the ECtHR

73 Othman (Abu Qatada) v. the UK of 2012, para. 194.

74 E. H. Morawska, op. cit., p. 67.

75 See also Baysakov and Others v. Ukraine, no. 54131/08, ECtHR judgement of 18.2.2010, paras 46-52.

76 Rule 39 Rules of Court (entry into force 14.11.2016; as amended by the Court on 4.7.2005, 16.1.2012 and 14.1.2013), http://www.echr.coe.int. 
examines the admissibility of the alien's expulsion (and extradition), when there are serious concerns of an actual life-threatening situation, torture, or inhuman or degrading treatment in the receiving State ${ }^{77}$. The Court may give these obligations a different form, but in the discussed cases they usually refer to the suspension of the execution of the expulsion decision. It should be stressed that only through consistent practice of the Court are interim measures now considered binding for State Parties ${ }^{78}$ and as such "are of key importance and play an important role in the mechanism of the Convention"79. At the current stage of development of Strasbourg case law, failure to submit to them by State Parties is considered an infringement not only of the Rules of the Court, which refers to them explicitly, but also a violation of Article 34 para. 3 of the Convention, as their implementation is considered a condition for the effective exercise of the right of individual complaint and violation of Article 46 of the Convention, to which the Court refers by indicating the obligation to execute the judgements of the ECtHR and supervision of the Committee of Ministers in this scope ${ }^{80}$.

Diplomatic guarantees and interim measures reflect the specific nature of the prevention mechanism in the area of the exclusion ban on the basis of the Convention. At the same time, it should be stressed that the aim is to prevent the materialization of the described risk from both private persons and the authorities of the host country. In both cases the purpose of its establishment and application is to reduce the probability of materialization of risk. As a rule, it is about individual and general prevention, including negative, consisting in deterring potential perpetrators of violations ${ }^{81}$. It needs not be only criminal prevention sensu

77 The applicant must apply to the Court for an interim measure. However, in matters relating to expulsion, the $\mathrm{ECtHR}$ requires the prior use of national remedies that may lead to the suspension of the decision (Article 13 of the Convention). Otherwise, the Court will refuse to apply rule 39 of the Rules of Court.

78 The key findings in this regard were those contained in Mamatkulov and Askarov of 2005.

79 As in Savriddin Dzhurayev v. Russia, no. 71386/10, ECtHR judgement of 25.4.2013, para. 213.

80 See Mamatkulov and Askarov v. Turkey of 2005, paras 101-129, 125-126, respectively. See also Y. Haeck, C. Burbano Herrera, L. Zwaak, Strasbourg's Interim Measures under Fire: Does the Rising Number of State Incompliances with Interim Measures Pose a Threat to the European Court of Human Rights?, 'European Yearbook on Human Rights' 2011, vol. 11, pp. 1-29.

81 Rantsev v. Cyprus and Russia, no. 25965/04, ECtHR judgement of 7.1.2010, para. 218. 
stricto, as shown by diplomatic assurances. In the context of the prevention mechanism, the ECtHR points to a whole range of organizational, technical and tactical measures characterized by multiplicity and diversity. Their multidimensional protective function is important. It seems that it dominates over other functions of the prevention obligation. It also best expresses the goal and object of the Convention as a whole. The preventive function is the effect of the protective function and, in this sense, it can be considered as complementary.

In the analysis of the ban on the expulsion of an alien in the event of the risk of ill-treatment in Strasbourg case law, attention should be paid to one more premise of this prohibition. It is linked to the health of the person to be expelled and the availability of appropriate medical care in the receiving State. In a situation where the person to be expelled is seriously ill, the State Party is obliged to determine whether there are substantial grounds so as to believe that if the expulsion decision is enforced, that person, because of a lack of access to appropriate medical care in the receiving State, will consequently be subject to treatment incompatible with Article 3 of the Convention .

For many years, the position of the ECtHR in the D. v. the UK case of 1997 was binding in this respect. The Court ruled then that the expulsion of the applicant in the terminal stage of Acquired Immune Deficiency Syndrome (AIDS) to his country of origin (the Caribbean Islands of St. Christopher), in which he had no one to provide him with care and in which the expensive medications needed in his condition were unavailable, would be tantamount to violation of the prohibition of inhuman treatment (Article 3 of the Convention). However, in conclusion of its findings, the Court clearly stated that "in addition to situations (...) in which death was imminent, there might be other very exceptional circumstances where the humanitarian considerations weighing against removal were equally compelling" ${ }^{82}$.

The abovementioned exceptionality of the ban on expulsion due to the alien's health condition was confirmed by the ECtHR in subsequent cases, including the N. v. the UK case of 2008, while explaining that:

(...) In the D. v. the United Kingdom case the very exceptional circumstances were that the applicant was critically ill and appeared to be close to death, could not be guaranteed any nursing or medical care in his country of origin and had no family there willing or able

Ibidem, paras 46-54. 
to care for him or provide him with even a basic level of food, shelter or social support ${ }^{83}$.

The Court then expressed the conviction that:

(...) it should maintain the high threshold set in D. v. the United Kingdom and applied in its subsequent case-law, which it regards as correct in principle, given that in such cases the alleged future harm would emanate not from the intentional acts or omissions of public authorities or non-State bodies, but instead from a naturally occurring illness and the lack of sufficient resources to deal with it in the receiving country ${ }^{84}$.

The above, very demanding requirements set out by ECtHR case law regarding the occurrence, in a given case, of the premise of prohibiting the expulsion of an alien, were upheld also in the Paposhvili v. Belgium case of 2016. The application was lodged by the applicant who was seriously ill and whose illness significantly reduced his predicted life expectancy ${ }^{85}$. In his complaint, he stated that the enforcement of the decision on his expulsion to Georgia, the country of his origin, would translate into violation of Article 3 or Article 8 of the Convention in an area of risk to his physical and mental integrity. This was because in Georgia the applicant would not have access to medical care, which was necessary given his difficult condition. In considering these allegations, the Court referred to the judgements contained in D. v. the UK and found that:

(...) "other very exceptional cases" which might raise an issue under Article 3 should be understood to refer to situations involving the removal of a seriously ill person in which substantial grounds had been shown for believing that he or she, although not at imminent risk of dying, would face a real risk, on account of the absence of appropriate treatment in receiving country or the lack of access to such treatment, of being exposed to a serious, rapid and irreversible decline in his or her state of health resulting in intense suffering or to a significant reduction in life expectancy ${ }^{86}$.

${ }^{83}$ N. v. the UK, no. 26565/05, ECtHR judgement of 27.5.2008, para. 42.

84 Ibidem, para. 43.

85 The applicant suffered from leukemia, hepatitis and a lung infection. The documents show the applicant died in June 2016, i.e. before the judgment was issued.

86 Paposhvili v. Belgium, no. 41738/10, ECtHR judgement of 13.12.2016, para. 183. 
When compared, the above findings indicate the Court defines in particular detail situations in which the State Party is bound by the prohibition on expulsion of an alien on account of his or her health. The Court therefore continues its practice to define the scope of positive prevention obligations, given that, already back in 1998, it determined these obligations could occur only under certain well-defined circumstances ${ }^{87}$.

There is no doubt that the situations in which the Court confirmed the existence of the positive obligation in question are of a special nature and can only exist under exceptional circumstances. They are so expressive that from the point of view of human rights they do not raise fundamental doubts as to the validity of their connection with these type of duties. As such, they constitute the threshold for State responsibility, which also has its source in the general approach of the Court to such obligations ${ }^{88}$.

The last point is that the Court clearly upholds only the precautionary nature of positive obligations in the cases at hand ${ }^{89}$. Therefore, they do not give rise to obligations on the part of the State Party to provide any specific material goods. The above issue appears naturally, given that in these matters considered are the health of the person to be expelled and their actual access to appropriate medical care. At the same time, the threshold of the State's responsibility is very high, but it was nevertheless lowered in the case of Paposhvili v. Belgium. In addition, it draws from specific findings of Strasbourg case law, since in the case Airey v. Ireland case of 1979, in the context of the obligation to provide access to court, the Court found that the possibility of extending the ECHR's scope to economic and social rights should not be a decisive factor against that interpretation as there is no water-tight division separating that sphere from the field covered by the Convention ${ }^{90}$.

This stance was confirmed by the ECtHR in subsequent judgements ${ }^{91}$, albeit with clear reservations, noting that:

The Convention does not guarantee, as such, socio-economic rights, including the right to charge-free dwelling, the right to work, the right judgement of 27.10.2004, para 47.

Cf. Osman v. the UK, no. 23452/94, ECtHR judgement of 28.10.1998, para. 115.

Cf. Omered v. Austria, no. 8969/10, ECtHR judgement of 20.9.2011.

Paposhvili v. Belgium of 2016, para. 186.

Airey v. Ireland, no. 6289/73, ECtHR judgement of 9.10.1979, para. 26.

E.g. Sidabras and Džiautas v. Lithuania, no. 55480/00 and 59330/00, ECtHR 
to free medical assistance, or the right to claim financial assistance from a State to maintain a certain level of living ${ }^{92}$.

These findings correspond with the assumption made by the Court that "in the evaluation of the existence of a social problem justifying specific measures in the field of social and economic policy, the States Parties tend to have a wide margin of appreciation" ${ }^{\prime 3}$. It should be agreed, however, that the Court, under the approach referred to in the literature as "integrated approach to the interpretation" of human rights, cites in particular Article 3 of the Convention in the context of certain economic and social aspects sensu stricto and then speaks of social or economic implications ${ }^{94}$. At the same time, it does not indicate the exact scope or nature of these implications, which introduces a certain degree of ambiguity and uncertainty, and arouses justified objections ${ }^{95}$.

An analysis of Strasbourg case law shows that the caution of the Strasbourg Court in approaching social implications does not occur or is far less noticeable in a situation in which a person remains in a detention facility or in a place over which the State exercises direct supervision ${ }^{96}$.

To sum up, the Paposhvila case confirms that when prohibiting the expulsion of a seriously ill alien to a country where, due to the possible lack of access to appropriate medical care, a real risk of ill-treatment may arise, the Court does not impose on the State Party to the ECHR the obligation to provide that person with appropriate medical care and decent living conditions, but rather obliges it to take measures to prevent the materialization of said risk, the existence of which the State knew or

92 E.g. findings in Pancenko v. Latvia, no. 40772/98, ECtHR decision of 28.10.1999, para. 2.

93 E.g. in Plechanow v. Poland, no. 22279/04, ECtHR judgement of 7.2.2009, para. 102.

94 E.g. in N.v. the UK of 2008, para. 44.

95 See I. Leijten, Defining the Scope of Economic and Social Guarantees in the Case Law of the ECtHR [in:] 'Shaping Rights in the ECHR: the Role of the European Court of Human Rights in Determining the Scope of Human Rights', Cambridge 2014, p. 115 et seq.; E. Koch, Justiciability of Indivisible Rights, 'Nordic Journal of International Law' 2003, vol. 72, no. 1, p. 25.

96 See cases that determined case law in that regard: Kudła v. Poland, no. 30210/96, ECtHR judgement of 26.10.2000; Keenan v. the UK, no. 2738/95, ECtHR judgement of 18.1.2001; Peers v. Greece, no. 28524/95, ECtHR judgement of 19.4.2001; Price v. the UK, no. 33394/96, ECtHR judgement of 10.7.2001; Renolde v. France, no. 5608/05, ECtHR judgement of 16.10.2008. 
should have known. A key condition for the responsibility of the State Party is therefore the rational possibility to predict the occurrence of a risk in the receiving State. Simply put, if the ECHR State Party could not predict the risk, it will not be held liable ${ }^{97}$. In this case, too, the Court invokes the positive obligation of prevention, even though the implementation of said obligation may in fact require taking measures with far greater financial repercussions than in the case of typical preventive measures. Consequently, the Court does not create a new type of positive obligation, but extensively interprets the scope of the prohibition of ill-treatment to include social aspects of life, in particular towards particularly vulnerable persons.

\section{Final remarks}

Developed in the application and interpretation of the ECHR, guarantees to protect an alien against expulsion in a situation where it would pose a real risk to their life or physical and mental integrity are of primary importance in Strasbourg case law and, as such, were indicated by the ECHR judicial bodies in the first place. As a result, protection against expulsion under Article 3 of the Convention extends far beyond the protection based on the Geneva Convention relating to the Status of Refugees $^{98}$.

In addition to the guarantee linked to the risk of ill-treatment (Article 3 of the Convention) and to the right to life (Article 2 of the Convention), the Court provides two more types of protection for aliens against arbitrary expulsion. The basis of the first type of these guarantees is the obligation of a State Party to the ECHR to respect their private and family life (Article 8 of the Convention), whereas the non-observance of the second obligation to protect an alien from the materialization of the risk in the receiving State would be a "flagrant violation" of the right to liberty and security (Article 5 of the Convention) or a "flagrant denial of justice" in relation to the right to a fair trial (Article 6 of the Convention) ${ }^{99}$.

97 As in Finogenov and Others v. Russia, no. 18299/03 and 27311/03, ECtHR decision of 18.3.2010, item A, para. 174.

98 Similarly in M. Kowalski, op. cit., p. 444.

99 See the case of Mamatkulov and Askarov v. Turkey, no. 46827/99, 46951/99, EtCHR judgment of 4.2.2005; see the dictum of the International Court of Justice in the Barcelona 
The case law review clearly shows that the scope of these rights is extended successively by including further issues related to the expulsion of the alien, gradually creating a material and procedural dimension of alien protection, including second-generation migrants, against arbitrary and ECHR-incompatible expulsion.

In the light of the analysis of the judicial practice of the Court, this process has clearly not been completed ${ }^{100}$.

\section{Bibliography}

1. Adamczyk A., Kryzys imigracyjny w UE i sposoby jego rozwiqzania, 'Przegląd Politologiczny' 2016, vol. 3

2. Bates E., The Evolution of the European Convention on Human Rights: from its Inception to the Creation of a Permanent Court of Human Rights, Oxford University Press, Oxford 2010

3. Boed R., The State of the Right of Asylum in International Law, 'Duke Journal of Comparative \& International Law' 1994, vol. 5

4. Capotorti F., Human Rights: the Hard Road Towards Universality, [in:] R. St. J. MacDonald, D. M. Johnston (eds.), 'The Structure and Process of International Law: Essays in Legal Philosophy Doctrine and Theory', Martinus Nijhoff Publishers, Dordrecht-Boston-London 1983

5. Czaputowicz J., Rola państwa w Unii Europejskiej, Centrum Europejskie Natolin, Warszawa 2004

6. D'Orsi C., The Au Convention on Refugees and the Concept of Asylum, 'Pace International Law Review Online Companion' 2012, vol. 3, no. 7

7. Dijk van P., F. van Hoof, A. van Rijn, L. Zwaak (eds.) Theory and Practice of the European Convention on Human Rights, Intersentia Publishers, Antwerp 2006

8. Duszczyk M., Kryzys migracyjny, 'Biuletyn Instytutu Zachodniego' 2015, vol. 205

Traction case, where the Court stated: "With regard to human rights, it should be noted that these also include protection against denial of justice" Barcelona Traction, Light and Power Company, Limited, Judgment, I.C.J. Reports 1970, p. 3., para. 91.

100 This statement is clearly confirmed by the case of N.D. and N.T. v. Spain, no. 8675/15 and 8697/15, ECtHR judgment of 3.10.2017. In this case the Court found that push-back operations at the Spanish border in the enclave of Melilla violated the right to an effective remedy and the prohibition of collective expulsion. 
9. Einarsen T., The European Convention on Human Rights and the Notion of an Implied Right to de facto Asylum, 'International Journal of Refugee Law' 1990, vol. 2

10. Florczak A., Uchodźcy w Polsce. Między humanitaryzmem a pragmatyzmem, Wydawnictwo Adam Marszałek, Torun 2003

11. Garlicki L. (ed.), Konwencja o Ochronie Praw Człowieka i Podstawowych Wolności. T.2. Komentarz do artykułów 19-59 oraz do Protokołów dodatkowych, C. H. Beck, Warszawa 2011

12. Goodwin-Gill G. S., J. McAdam, The Refugee in International Law, Oxford University Press, Oxford 2007

13. Grahl-Madsen A., Territorial Asylum, Swedish Institute of International Law, Almqvist \& Wiksell, Stockholm 1980

14. Grahl-Madsen A., The Status of Refugees in International Law, Edition, reprint. Publisher: A. W. Sijthoff, 1972. Original from the University of California 1966

15. Gronowska B., Europejski Trybunał Praw Człowieka. W poszukiwaniu efektywnej ochrony praw jednostki, Wydawnictwo TNOiK, Toruń 2011

16. Haeck Y., C. Burbano Herrera, L. Zwaak, Strasbourg's Interim Measures under Fire: Does the Rising Number of State Incompliances with Interim Measures Pose a Threat to the European Court of Human Rights?, 'European Yearbook on Human Rights' 2011, vol. 11

17. Hailbronner K., Molding a New Human Rights Agenda, 'The Washington Quarterly' 1985, vol. 8

18. Knox J. H., Horizontal Human Rights Law, 'American Journal of International Law' 2008, vol. 102

19. Koch E., Justiciability of Indivisible Rights, 'Nordic Journal of International Law' 2003, vol. 72

20. Kourula P., Broadening the Edges: Refugees Definition and International Protection Revisited, Martinus Nijhoff Publishers, The Hague 1997

21. Kowalski M., Pomiędzy uznaniowościq a zobowiq̨zaniem: podstawy prawnomiędzynarodowej ochrony uchodźców, 'Politeja 2016, vol. 1(5)

22. Krantz J, Państwo i jego suwerennośc, 'Państwo i Prawo' 1996, vol. 7

23. Kwiecień R. (ed.), Państwo a prawo międzynarodowe jako system prawa, Wydawnictwo UMCS, Lublin 2015

24. Kwiecień R., Suwerenność państw: rekonstrukcja i znaczenie idei w prawie międzynarodowym, Wydawnictwo Zakamycze, Kraków 2004

25. Lauterpacht H., International Law and Human Rights, Publisher: Stevens \& Sons, Ltd., London 1950

26. Lauterpacht H., The Universal Declaration of Human Rights, 'British Yearbook of International Law' 1948, vol. 25

27. Leijten I., Defining the Scope of Economic and Social Guarantees in the Case Law of the ECtHR, [in:] Brems E., Gerards J. (eds.), 'Shaping Rights in the ECHR: 
the Role of the European Court of Human Rights in Determining the Scope of Human Rights', Cambridge University Press, Cambridge 2014

28. Madsen M. Rask, From Cold War Instrument to Supreme European Court: the European Court of Human Rights at the Crossroads of International and National Law and Politics, 'Law \& Social Inquiry' 2007, vol. 32

29. Martin D. A., Reforming Asylum Adjudication: On Navigating The Coast of Bohemia, 'University of Pennsylvania Law Review' 1990, vol. 138

30. Morawska E. H., Zobowiqzania pozytywne państw-stron Konwencji o ochronie praw człowieka i podstawowych wolności, Wydawnictwo UKSW, Warszawa 2016

31. Morgenstern F., The Right of Asylum, 'British Yearbook of International Law' 1949, vol. 26

32. Pettiti L. E., E. Decaux, P. H. Imbert (eds.), La Convention européenne des droits de l'homme: Commentaire article par article, Économica, Paris 1998

33. Prakash Sinha S., Asylum and International Law, Martinus Nijhoff, The Hague 1971

34. Sivakumaran S., Impact on the Structure of International Obligations, [in:] M. T. Kamminga, M. Scheinin (eds.), 'The Impact of Human Rights Law on General International Law', Oxford University Press, Oxford 2009

35. Tomuschat Ch., A Right to Asylum in Europe, 'Human Rights Law Journal' 1992, vol. 13

36. Warbrick C., The European Response to Terrorism in an Age of Human Rights, 'European Journal of International Law' 2004, vol. 15

37. Weis P., The United Nations Declaration on Territorial Asylum, 'Canadian Yearbook of International Law' 1969, vol. 7 